IDEA - Studia nad strukturą i rozwojem pojęć filozoficznych $\mathrm{XXIX/1}$

Białystok 2017

\title{
Krzysztof Ostasz
}

(Białystok)

\section{NIEROZUMIENIE RUCHU IJEGO KONSEKWENCJE}

\section{Problem ruchu}

Parmenides z Elei i Heraklit z Efezu przeszli do historii filozofii jako oponenci w sporze o istnienie ruchu i wielości. Większość filozofów, poczynając od Eleatów, odrzucała świadectwo zmysłów, ponieważ ukazują one złożoność i zmienność, które są niepojęte rozumem. Heraklit odwrotnie - uznawał za fałszywe świadectwo zmysłów, o ile ukazywały jedność i stałość. Fryderyk Nietzsche twierdził, że my sami jesteśmy fałszerzami, i to „Rozum» jest przyczyną, iż fałszujemy świadectwo zmysłów. Zmysły nie kłamią, o ile okazują stawanie się, przemijanie, zmianę"1.

Jak zauważył Henri Bergson: „gdyby filozofowie byli przeświadczeni o realności zmiany i podjęli wysiłek jej uchwycenia, wszystko stałoby się prostsze"2. W pewnym sensie nawet nieskończenie prostsze. Ponieważ racjonalna część naszego umysłu jest zdecydowanie eleacka, nie potrafimy rozumieć ruchu inaczej niż w następujący sposób: jeśli przedmiot był w punkcie $A$, a później w punkcie $B$, to znaczy, że wystąpił ruch z punktu $A$ do $B$. Jeśli natomiast najkrótsza droga

${ }^{1}$ F. Nietzsche, Zmierzch bożyszcz, przeł. S. Wyrzykowski, Warszawa 1991, s. 23.

${ }^{2}$ H. Bergson, Postrzeżenie zmiany, przeł. P. Beylin, w: I. Wojnar, Bergson, Warszawa 1985, s. 248 (Wszystkie cytowane w tej pracy fragmenty tekstów H. Bergsona pochodzą z książki I. Wojnar i do niej odnoszą się podane numery stron.). 
pomiędzy dwoma dowolnymi punktami $A$ i $B$ wiedzie przez nieskończenie wiele punktów pośrednich, to tak pojmowany ruch komplikuje się w nieskończoność, a wręcz staje się niemożliwy. Powstaje pytanie: Jak cokolwiek może w skończonym czasie znaleźć się w nieskończenie wielu miejscach? W żadnym miejscu nie mogłoby być ani chwili, w przeciwnym razie najkrótsze chwile nieskończenie zwielokrotnione dadzą w sumie nieskończony czas. Tym tropem podążał uczeń Parmenidesa - Zenon z Elei - tworząc słynne aporie, mające dowodzić niemożliwości ruchu. Diogenes z Synopy miał cynicznie obalać te dowody po prostu spacerując. Jeśli paradoksy Zenona czegoś dowodzą to tylko niemożności zrozumienia ruchu w sposób racjonalny.

Wszystko, co żyje, porusza się. Ruch jest nieodłącznym atrybutem życia, a „dla istoty świadomej istnieć - znaczy zmieniać się”. Dlatego też wszystkie niejasności, związane $\mathrm{z}$ zagadnieniem ruchu, przyczyniają się automatycznie do zaciemnienia zjawiska życia. Jose Ortega y Gasset dostrzega, iż w opracowaniu zagadnienia życia - podobnie jak w opracowaniu zagadnienia ruchu - filozofowie dopuścili się swoistego zaniedbania: „w całej historii filozofii nie zdołano stworzyć odpowiedniej terminologii, przy pomocy której można by mówić formalnie o fenomenie życia $[\ldots]$ powinno to być powodem do wstydu dla całej tradycji filozoficznej”4.

Jak to się stało, że nie rozwinięto myśli Heraklita i nie potraktowano zjawiska ruchu z należytą mu rzetelnością, a niemalże cały wysiłek filozofów na ponad dwa tysiąclecia zwrócił się w kierunku wskazanym przez Parmenidesa? Gdy już zdamy sobie sprawę, że ruch dostępny jest nam tylko dzięki zmysłom, a ze zmysłowości właśnie wywodzą się wszelkie instynkty, wówczas odpowiedzi na powyższe pytanie dostarczy nam Nietzsche: „Ateny chyliły się do upadku [...] Instynkty znajdowały się wszędzie w rozpasaniu [...] «Popędy pragną stać się tyranem; trzeba wynaleźć przeciw-tyrana, który jest silniejszy»" ${ }^{5}$. Wtedy pojawił się Sokrates. „W rozsądku widziano wówczas zbawcę [...], wybór był tylko jeden: albo zginać, albo być rozumnym - do absurdu"6. Grecy przestraszyli się zezwierzęcenia i postanowili rozwijać tę cechę, która ich odróżniała od innych ssaków. Popęd rozumu okazał się niemniej silny i równie nienasycony jak popęd

\footnotetext{
${ }^{3}$ Tenże, Ewolucja twórcza, przeł. F. Znaniecki, w: dz. cyt., s. 210.

${ }^{4}$ J. Ortega y Gasset, Dehumanizacja sztuki i inne eseje, przeł. P. Niklewicz, Warszawa 1980, s. 438 .

${ }^{5}$ F. Nietzsche, Zmierzch..., dz. cyt., s. 18.

${ }^{6}$ Tamże, s. 19-20.
} 
zmysłów. Twory (idee) rozumu nabrały pozorów realności, a jego ograniczenia mylono z ograniczeniami świata. Od tamtej pory tworzono obraz świata na miarę ludzkiego rozumu, ale przecież „Daremnym trudem jest upraszczanie spraw tylko z tego względu, że samemu się jest prostym i nieskomplikowanym" ".

Rozum musi zatrzymywać i dzielić. Nie ogarnia całości inaczej niż przez analizę i syntezę części. Musi wycinać sobie z rzeczywistości części, które umie zrozumieć. A zrozumiałe jest tylko to, co nieruchome, z konieczności więc pożądane przez rozum pojęcia są statyczne. Według Nietzschego filozofia skupiając nadmierną uwagę na pojęciach, zapomniała o rzeczywistości. „Wszystko to, czem zajmowali się filozofowie od tysiącleci, było mumiami pojęciowemi; nic rzeczywistego nie uchodziło z rąk ich żywcem"

Podobnie Ortega twierdzi, że ogranicza nas „eleacka ontologia. [...] Prototypem takiego sposobu bytowania, który jest określony, ustalony i aktualny [...] był byt pojęć i przedmiotów matematycznych, byt niezmienny, byt-zawszejednaki. Ponieważ w otaczającym świecie spotyka się rzeczy, które są zmienne, które są «w ruchu», zaczyna się negować ich realność. Arystoteles słusznie odrzuca podobny absolutyzm [...]. Szuka w rzeczy zmiennej tego, co w samej zmianie pozostaje stałe [...]. Physis była dla niego niezmienną zasadą zmienności"

Sposobem uchwycenia stałości w zmianie jest rachunek różniczkowy, opracowany niezależnie przez Leibniza i Newtona w XVII w. Jeśli zmienia się położenie $x$, to szuka się stałej prędkości $v=d x / d t$, jeśli prędkość się zmienia, to może jest stałe przyspieszenie $a=d v / d t$, a może chociaż stała zmiana przyspieszenia $a^{\prime}=d a / d t$, itd. Rozumiemy prędkość, ale nie sam ruch. Rozumiemy kolejne pochodne, ale nie samą zmianę. Aby jakkolwiek zbliżyć się racjonalnie do zmienności, szukamy w niej stałości. Matematyzacja poznania, realizowana na gruncie pozytywizmu, jest właśnie usilną próbą poszukiwania stałości w zmienności. „Tak więc u Comte'a i Stuarta Milla wszystko, niczym na gwoździu, zawieszone jest na «stałości praw natury»" ${ }^{10}$. Nauka pozytywna opierając się na stałości i szukając stałości jest kontynuacją szkoły eleackiej.

A jak rozwijać poglądy Heraklita? Należy próbować uchwycić substancjalność samej zmiany. Bergson proponuje uznać, że stałość nie istnieje. „Jeśli ruch

\footnotetext{
${ }^{7}$ J. Ortega y Gasset, Dehumanizacja..., dz. cyt., s. 274.

${ }^{8}$ F. Nietzsche, Zmierzch..., dz. cyt., s. 22.

${ }^{9}$ J. Ortega y Gasset, Po co wracamy do filozofii?, przeł. A. Jancewicz, Warszawa 1992, s. 186.

${ }^{10}$ Tamże.
} 
nie jest wszystkim, jest niczym; i jeśli z góry założymy, że bezruch może być rzeczywistością, ruch prześliźnie się nam między palcami wtedy właśnie, gdy będziemy przekonani, że go trzymamy"11. Jeśli tylko dopuściliśmy możliwość statycznych stanów w procesie ruchu, „Zamknęliśmy oczy na prawdziwą rzeczywistość"12, i natychmiast popadliśmy w pozorne problemy metafizyczne.

\section{Sztywność pojęć}

Nauki pozytywne posługujące się statycznymi pojęciami są jednocześnie konsekwencją niezrozumienia ruchu oraz przyczyną ugruntowania tego niezrozumienia. Ostre nazwy, precyzyjne definicje, niezmienne prawa naukowe, matematyczne modele, wysublimowane teorie - wszystkie te narzędzia racjonalnego poznania wprowadzają porządek i spokój w dziedzinie naszej wiedzy o świecie. Uporządkować jednak można tylko nieruchome przedmioty, wszystko co zmienne albo żywe wymknie się z szufladek racjonalisty. „My ludzie współcześni - pisze Ortega - cały świat mamy poszufladkowany, jesteśmy zwierzętami klasyfikującymi. Każda dziedzina nauk jest taką szufladką, a w każdej z szufladek zamknięta jest olbrzymia masa odłamków rzeczywistości, które odrąbywaliśmy przez wieki od wielkiej macierzystej skały natury. [...] By zebrać martwy, pozbawiony ducha skarb, musieliśmy naturę poćwiartować, musieliśmy ją uśmiercié"13. Ludzie - zwierzęta $\mathrm{z}$ instynktem klasyfikacji, z popędem racjonalizacji - ćwiartują świat definicjami na coraz drobniejsze pojęcia. Ostrzenie nazw i stosowanie coraz bardziej wyrafinowanych modeli, to ostrzenie narzędzi do analizy rzeczywistości. W wyniku analizy pojęciowej powstają abstrakcyjne, oderwane od rzeczywistości twory. Język, który miał tłumaczyć świat, stał się zasłoną rzeczywistości, „a wszelkie słowo maską ${ }^{14}$.

Ortega zauważa, że większość ludzi, „kiedy znajdzie się w posiadaniu nazwy czegoś, idei, popada w niezdolność dostrzeżenia tego czegoś, owej rzeczywistości, której nazwania i ideacji dokonuje. Nazwa i idea stają pomiędzy rzeczami a nami niczym nieprzezroczysty ekran. Ciekawe, że idee, których celem jest ułatwienie nam jasnego widzenia rzeczywistości, służą wielu ludziom do

\footnotetext{
${ }^{11}$ H. Bergson, Postrzeżenie..., dz. cyt., s. 262-3.

${ }^{12}$ Tamże, s. 264.

${ }^{13}$ J. Ortega y Gasset, Dehumanizacja..., dz. cyt., s. 75.

${ }^{14}$ F. Nietzsche, Poza dobrem i ztem, przeł. S. Wyrzykowski, Warszawa 1911, s. 275.
} 
czegoś wręcz przeciwnego: do wypłoszenia rzeczywistości, do obrony przed adekwatnym jej postrzeganiem" ${ }^{15}$. Wygląda na to, że przy próbie wyjścia w świat za pomocą rozumu, wpadamy w sieć pojęciową, którą sami sobie zastawiliśmy. Realizm pojęciowy Platona jest tego najlepszym przykładem. „Idea - sądzi Ortega - zamiast być narzędziem myślenia, staje się jego przedmiotem i celem" ${ }^{16}$. Idea powstaje $\mathrm{w}$ wyniku abstrahowania, i właśnie dlatego nie zawiera całego bogactwa i złożoności konkretnej rzeczy, z której abstrahuje. Idea jest zawsze uboższa jakościowo od konkretu. „Słowo, które określa jedynie najpospolitszą funkcję rzeczy i jej banalny aspekt, wsuwa się między nią a nas" ${ }^{\prime 17}$. Ma ono jednak taką zaletę, że jest stałe, a to znaczy, że jest racjonalnie uchwytne dla naszego rozumu. Ta niezmienność jest jednak cechą pojęć, i nie należy jej przypisywać rzeczywistości. „Trwałość form w ludzkim życiu jest złudzeniem wynikającym z toporności pojęć, którymi się posługujemy myśląc o nich"18.

Sztywność pojęć, przenosi się na zdania zawierające nazwy. Język złożony ze zdań jest obciążony jakby wadą genetyczną sztywności, przez co ogranicza nasze zdolności poznawcze. „Język nie tylko utrudnia wyrażenie pewnych myśli, lecz z tych samych przyczyn przeszkadza w odbiorze innych, paraliżuje pewne kierunki naszego rozumowania" ${ }^{\prime 1}$. Język jest narzędziem służącym do komunikacji i właściwie wszelkie jego ograniczenia i wady są ograniczeniami i wadami komunikacyjnymi. Nastąpiło jednak sprzężenie zwrotne: język, który służył wyrażaniu myśli, sam zaczął zmieniać sposób myślenia. Zaczęliśmy myśleć, jakbyśmy mówili, a nawet myślenie na wzór mówienia uznajemy za jedynie słuszne. Kategorie logiczne stały się formami naszego myślenia. „Ale właśnie ta techniczna forma, która czyni prawdę widzialną dla rozumu, ukrywa ją znowu przed uczuciem; albowiem - niestety - intelekt najpierw musi zniszczyć przedmiot wewnętrznego zmysłu, jeśli chce go sobie przyswoić. Filozof, podobnie jak chemik, związek znajduje tylko dzięki rozkładowi [...]. Aby uchwycić przelotne zjawisko, musi zakuć je w kajdany prawideł, w strzępy pojęć rozszarpać jego piękne ciało i przechować w nędznym szkielecie słów jego żywego ducha”20.

${ }^{15}$ J. Ortega y Gasset, Bunt mas i inne pisma socjologiczne, przeł. P. Niklewicz i H. Woźniakowski, Warszawa 1982, s. 733.

${ }^{16}$ Tenże, Debumanizacja..., dz. cyt., s. 292.

${ }^{17}$ H. Bergson, Smiech, przeł. I. Wojnar, w: dz. cyt., s. 192.

${ }^{18}$ J. Ortega y Gasset, Uwagi o myśleniu, jego teurgia i jego demiurgia, przeł. R. Gaj, w: R. Gaj, Ortega y Gasset, Warszawa 2007, s. 284.

${ }_{19}$ Tenże, Bunt..., dz. cyt. s. 612-613.

${ }^{20}$ F. Schiller, Listy o estetycznym wychowaniu cztowieka i inne rozprawy, przeł. I. Krońska i J. Prokopiuk, Warszawa 1972, s. 42. 
Zasady języka kształtowały się w kierunku jego użyteczności w komunikacji. Bycie zrozumiałym dla drugiego stało się priorytetem, ale bycie zrozumiałym dla samego siebie jest czymś innym. Myślenie nie musi być ograniczane przez zasady języka. Wpływ, jaki wywiera język na myślenie, objawia się w tym, że: „Rzeczy widzimy poprzez idee [...]. Jednak odległość dzieląca ideę od rzeczy jest nie do pokonania. Przedmiot rzeczywisty zawsze przewyższa pojęcie, w którym ma być zawarty, jest czymś więcej i czymś innym niż to, co zawiera jego idea. Pojęcie pozostaje zawsze prostym wzorem, rodzajem rusztowania, przy pomocy którego usiłujemy dojść do rzeczywistości. Ale natura ludzka skłania nas do uznawania za rzeczywistość tego, co o niej myślimy [...]. Tęsknota za rzeczywistością prowadzi nas do jej idealizacji. Jest to wrodzona «ludzka» właściwość"21. Natura ludzka to pragnienie miłej pewności, której gwarantem jest niezmienność, stąd nasza skłonność do idealizacji. Pewne i niezmienne jest to, co konieczne. Wszystkie te pożądane cechy zawiera logika, i właśnie ona tworzy owo rusztowanie, z którego chcemy dosięgnąć rzeczywistości. Ludwig Wittgenstein twierdzi wręcz, że „Zdanie konstruuje pewien świat z pomocą rusztowania logicznego"22. Świat ten nie jest jednak naszym światem, jest nam obcy. Zdania logiki nie są naszymi zdaniami, są niezależne od nas. „A to znaczy, że w logice nie my wyrażamy przez znaki, co chcemy, lecz że przemawia w niej sama konieczna ich natura"23.

\section{Zasłona języka}

Ludwig Wittgenstein, w jednym z listów, tak pisze o swoim Traktacie: „moja praca składa się $\mathrm{z}$ dwóch części: $\mathrm{z}$ tego co $\mathrm{w}$ niej napisałem, oraz z wszystkiego, czego nie napisałem. I właśnie ta druga część jest ważna”24. Wittgenstein wie, że istnieje coś, czego nie można wypowiedzieć i że jest to ważniejsze od tego, co wypowiedzieć się da. Całe jego dzieło jest w zasadzie o tym, co jest możliwe do wypowiedzenia. Przyjrzyjmy się zatem, jakie ograniczenia ma język według austriackiego filozofa.

\footnotetext{
${ }^{21}$ J. Ortega y Gasset, Dehumanizacja.., dz. cyt., s. 308.

${ }^{22}$ L. Wittgenstein, Tractatus Logico-philosophicus, przeł. B. Wolniewicz, Warszawa 2000, teza 4.023 .

${ }^{23}$ Tamże, teza 6.124.

${ }^{24}$ Tamże, s. VIII
} 
„W zdaniu myśl wyraża się w sposób zmysłowo postrzegalny”25. Ja uzmysławiam swoje myśli bez ich realizacji w świecie zmysłowym, a zatem zdania ewidentnie są przeznaczone innemu odbiorcy. Stąd wynika, że język, na który składa się ogół zdańn ${ }^{26}$, służy do komunikacji. Bergson oraz Ortega y Gasset twierdzili, że słowa i pojęcia zasłaniają rzeczywistość, a Wittgenstein dodaje: „Język przesłania myśl”"27. Czy to znaczy, że myśl jest bogatsza niż język, i że nie może on wyrazić pełnej myśli?

Kolejna teza, która ogranicza możliwości języka głosi: „Zdanie może jedynie powiedzieć, jaka jest rzecz, a nie czym jest"28. Najdokładniejszy opis jabłka nie odda tego, czym ono jest. To, czym są rzeczy, wykracza poza możliwości języka. Możemy budować zdania o aspektach rzeczy, która ma ich nieskończenie wiele, i z tej już tylko racji sama rzecz przekracza możliwości języka. Definicje ostensywne uzupełniają (a być może dopełniają w dziedzinie komunikacji) komunikaty językowe. Są to rozłączne sposoby porozumiewania się, bo „Co można pokazać, tego nie można powiedzieć”29. Pokazywanie należy do dziedziny zmysłów, a mówienie do dziedziny rozumu. Są one radykalnie różne, ale komplementarne.

Ostatnią tezę - „O czym nie można mówić, o tym trzeba milczeć” ${ }^{30}$. można zrozumieć w kontekście całego Traktatu. Mówienie należy tu rozumieć jako wypowiadanie sensownych. Zatem milczenie nie obejmuje zdań bezsensownych, wyrażających myśli irracjonalne. Metafora jest właśnie dosłownie pozbawiona sensu. To, co można pokazać, tego nie można powiedzieć jasno, ale można pokazać (zainspirować) metaforycznie.

Rozum, nie odnajdując sensu w metaforycznym (bezsensownym) zestawieniu wyrazów, nie osiąga satysfakcji i pozostając $\mathrm{w}$ stanie pobudzenia, nie zatrzymuje się w drodze do opisywanego przez tę metaforę świata. Myśl nie krzepnie na granicy wyznaczonej sztywnymi pojęciami, ale płynnie ją przekracza. Takie świeże metafory sprawiają, że język staje się przeźroczysty.

\footnotetext{
${ }_{25}$ Tamże, teza 3.1.

${ }^{26}$ Tamże, teza 4.001.

${ }^{27}$ Tamże, teza 4.002.

${ }^{28}$ Tamże, teza 3.221.

${ }^{29}$ Tamże, teza 4.1212.

${ }^{30}$ Tamże, teza 7.
} 


\section{4. Świeżość metafor}

Jose Ortega y Gasset, podobnie jak Ludwig Wittgenstein, uważa, że oprócz tego, co można wyrazić za pomocą zdań, istnieje coś jeszcze. „Język jest zawsze otoczony kordonem niewysłowienia. Ograniczenie to dotyczy tego wszystkiego, co absolutnie nie daje się wypowiedzieć w żadnym języku"31. Twierdzi on także, że aby zrozumieć ludzką rzeczywistość trzeba „wyrzucić na śmietnik wszystkie statyczne pojęcia i nauczyć się myśleć pojęciami nieustannie będącymi w ruchu" ${ }^{\prime 2}$. Czyli metaforami, które wprowadzają ruch pomiędzy statyczne pojęcia. Poprzez metaforyczne zestawienie stabilnych znaków wytwarza się między nimi pewnego rodzaju napięcie, które wyraża ruch. Nie możemy oprzeć się na konwencjonalnym rozumieniu pojęć zestawionych w metaforze, zwykły schemat rozumowania nie sprawdza się. Nasza uwaga krąży między pojęciami i odnajduje ich wspólny sens gdzieś między nimi. Sens metaforyczny jest sensem nie wprost. Przez metaforę wyraża się to, co dosłownie niewyrażalne. Metafora sięga dalej i zwiększa zasięg języka. Metafora rozwija możliwości opisowe języka, bo „zwykłe słowa przekazują tylko to, co już znamy; właśnie metaforą możemy najlepiej objąć to, co nowe"33.

Metafory nie są jednoznaczne. Dlatego nauki silące się na obiektywność unikają poezji. Każdy rozumie metaforę w kontekście osobistych doświadczeń. Dlatego np. wiersze miłosne rozumieją tylko ci, którzy miłości doświadczyli. Metafory bardziej się czuje niż rozumie. Metaforycznie o metaforze można powiedzieć, że jest zmysłowym rozumowaniem. To, jakie metafory do nas przemawiają, świadczy o nas i o naszych doświadczeniach. Jakieś hipotetyczne istoty, które nie doświadczają na co dzień istnienia kierunku góra-dół, mogłyby mieć problem ze zrozumieniem wyrażenia: osiągnąć szczyt możliwości. Zatem ścisłe pojęcia niezbędne są do kontaktu $\mathrm{z}$ innymi, metafory zaś do kontaktu z samym sobą i z podobnymi nam.

Ortega przypisuje metaforze olbrzymią wartość. „W metaforze kryją się chyba potencjalnie największe możliwości człowieka. Jej skuteczność graniczy z magią, wydaje się ona narzędziem stworzenia, które Bóg przez pomyłkę zo-

${ }^{31}$ J. Ortega y Gasset, Debumanizacja.., dz. cyt., s.391.

32 Tenże, Uwagi..., dz. cyt., s. 285.

33 Arystoteles, Retoryka. Retoryka dla Aleksandra. Poetyka, przeł. H. Podbielski, Warszawa 2009 , wers 1410 b. 
stawił we wnętrzu jednej ze stworzonych przez siebie istot" ${ }^{\prime 34}$. W wyrażeniu metaforycznym, pomiędzy zestawionymi ze sobą pojęciami dochodzi do nieoczywistej syntezy. W efekcie powstaje nowe pojęcie, które wykracza poza proste złożenie pojęć składowych, mamy do czynienia ze swoistą synergią. „W metaforze - sądzi Ortega - dochodzi do zderzenia się dwu bytów rzeczywistych, w którego wyniku wzajemnie się one unicestwiają [...]. Metafora staje się duchową bombą atomową. W wyniku wzajemnego unicestwienia się owych rzeczywistości powstaje nowa, wspaniała rzecz, jaką jest nierzeczywistość, irracjonalność" ${ }^{35}$. Zderzanie to jest pokrewne dialektycznemu łączeniu przeciwieństw, w wyniku którego także powstaje nowa jakość.

Efekt zestawienia metaforycznego jest nieprzewidywalny, bo nie jest schematyczny. Metafory nie można wydedukować, można ją odkryć. „Ortega mówi, że każda metafora jest odkryciem «nowego prawa we wszechświecie»" ${ }^{36}$. Każda metafora, którą sobie przyswoimy, przyczynia się do poszerzenia naszej wiedzy o świecie. Świeża metafora znajduje sobie miejsce w strukturze naszych pojęć statycznych jakby rozpychając się. Robi ona wyłom w warstwie pojęciowej przesłaniającej nam rzeczywistość. Robi wokół siebie mikro rewolucję. Rewolucyjność metafory polega na tym, że nie można jej przewidzieć, pojawia się spoza systemu.

„Istotą metafory jest rozumienie i doświadczanie pewnego rodzaju rzeczy $\mathrm{w}$ terminach innej rzeczy”37. Rozumienie to jest tylko częściowe. Pojęcie metaforyczne odsłania część aspektów innego pojęcia, a resztę aspektów zasłania. Metafory, jak każdego innego narzędzia można zatem używać źle. Metafora, która krzepnie, która staje się oczywista i przestaje pobudzać naszą uwagę, staje się potencjalną przyczyną pomyłek, pozornie skomplikowanych problemów $\mathrm{i}$,wielkich” pytań. „Metafora jest niezastąpionym narzędziem w pracy umysłowej, jest formą naukowego myślenia. Może się natomiast zdarzyć, że naukowiec pomyli się i myśląc o czymś w sposób pośredni czy metaforyczny przypuszcza, iż myśli w sposób prosty i bezpośredni. [...] Błąd w stosowaniu metody nie prze-

${ }^{34}$ J. Ortega y Gasset, Dehumanizacja..., dz. cyt., s. 304.

35 Tamże, s. 429.

${ }^{36}$ R. Gaj, Ortega y Gasset, Warszawa 2007, s. 93.

${ }^{37}$ G. Lakoff, M. Johnson, Metafory w naszym życiu, przeł. T. P. Krzeszowski, Warszawa 2010, s. 31. 
kreśla automatycznie jej wartości. Poezja jest metaforą, nauka natomiast metafor używa, i nic więcej. Można by również powiedzieć: i nic mniej”38.

Większość ludzi uważa, że metafory są środkiem wyrazu poety i że na co dzień można się bez nich obejść. George Lakoff i Mark Johnson dowodzą jednak, że nie tylko nasz codzienny język jest metaforyczny, ale także „procesy myślenia są w głównej mierze metaforyczne" ${ }^{39}$. Wskazując metafory tam, gdzie nie widać ich na pierwszy rzut oka, wykazują oni powszechne ich stosowanie także $\mathrm{w}$ teoriach naukowych. Takie pozornie ścisłe pojęcia używane w modelach nauk pozytywnych sprawiają, że nie są one tak obiektywne, za jakie uchodzą. Na nieobiektywność nauk empirycznych zwrócił uwagę Paul Feyerabend, który radzi, jak używać pojęć, aby nie popaść w bezpłodny dogmatyzm: „Nie powinniśmy przywiązywać zbyt wielkiej wagi do tego «co rozumiemy» przez dany zwrot, będąc gotowi zmienić cokolwiek powiedzieliśmy odnośnie owego rozumienia, gdy tylko powstanie taka potrzeba. [...] Podatność na zmiany, a nawet niedbałość w sprawach semantycznych, jest wstępnym warunkiem rozwoju naukowego" ${ }^{40}$.

\section{Racjonalność modeli}

Gdy już pojawiły się pojęcia, w efekcie niezrozumienia ruchu, kolejnym stadium pogrążania się w bezruchu jest budowanie modeli. Podobnie jak pojęcia, modele miały pomagać nam w dotarciu do rzeczywistości, i podobnie jak pojęcia, modele także zaczęły nam ową rzeczywistość zasłaniać. Ludzie na kolejnym poziomie metodę poznania mylą z jego celem. Spowodowane jest to uleganiem czemuś, co można nazwać popędem rozumu ku racjonalności, lub inercją umysłową. „Dlatego też dość nam iść po pochyłości naszego umysłu, aby stać się matematykami" ${ }^{11}$.

Człowiek aby odpocząć od ciężaru egzystencji chętnie ucieka w świat nierzeczywisty, który sam tworzy. Świat nauki, jako wytwór człowieka, jest światem, „który nie istnieje, który jest żartem i farsą" ${ }^{2}$. Kiedy uwierzymy w ten świat, nasze życie również stanie się farsą, staniemy się zakładnikami naszej ra-

\footnotetext{
${ }^{38}$ J. Ortega y Gasset, Dehumanizacja..., dz. cyt., s. 217.

${ }^{39}$ G. Lakoff, M. Johnson, dz. cyt., s. 32.

${ }^{40}$ P. K. Feyerabend, Jak być dobrym empirystą?, przeł. K. Zamiara, Warszawa 1979, s. 50.

${ }^{41}$ H. Bergson, Ewolucja..., dz. cyt., s. 211.

${ }^{42}$ J. Ortega y Gasset, Dehumanizacja..., dz. cyt., s. 441.
} 
cjonalności. Na powrót możemy odzyskać wolność, gdy to, co uchodzi za rzeczywistość, utraci całą swoją powagę. Ortega słusznie zauważa, że „racjonalizm jest formą intelektualnej bigoterii: w przemyśleniach dotyczących rzeczywistości stara się nie brać jej pod uwagę" ${ }^{\text {"3 }}$. Mówimy o prawach nauki, zastępując nimi prawa przyrody, których doświadczamy. Wittgenstein doskonale oddał problematyczność relacji pomiędzy teorią a doświadczeniem w trzech poniższych tezach Traktatu:

„6.36 Gdyby istniała jakaś zasada przyczynowości, to mogłaby brzmieć: «Istnieją prawa przyrody».

Ale tego właśnie nie da się powiedzieć: to się widzi.

6.363 Indukcja polega na tym, że przyjmujemy najprostsze prawo dające się pogodzić $\mathrm{z}$ naszym doświadczeniem.

6.3631 Nie ma to jednak logicznego uzasadnienia, lecz jedynie psychologiczne.

Jest jasne, że nie ma podstaw, by sądzić, że zajdzie rzeczywiście przypadek najprostszy" ${ }^{\prime \prime}$.

W nieco innej formie, ten sam problem diagnozuje Ortega, używając pojęcia „frazes”, które obrazuje to, czym jest teoria lub prawo naukowe. Według jego definicji „Frazes - to formuła intelektualna wykraczająca poza granice rzeczywistości, o której mówi. Frazes zamiast dostosować się do rzeczy i zakończyć się tam, gdzie kończy się dana rzecz, zaokrągla rzeczywistość" ${ }^{45}$. Indukcja - podstawowe narzędzie nauk pozytywnych - jest przejawem naszego lenistwa i nierzetelności. Natomiast „Racjonalizm, myślenie frazesami, to po prostu inercja umysłowa" ${ }^{\text {. }}$.

Bergson świetnie zdemaskował podstępne działanie leniwego i racjonalnego rozumu. „Myśl, że moglibyśmy dla nowego przedmiotu potrzebować stworzyć w całości nowe pojęcie, a może nową metodę myślenia, budzi w nas głęboki wstręt. [...] nasz umysł woli oznajmić raz na zawsze, z dumną skromnością, że poznawać będzie tylko względność i że poznanie absolutu do niego nie należy: to wstępne oznajmienie pozwala mu stosować bez skrupułu swą zwykłą metodę

\footnotetext{
${ }^{43}$ Tenże, Bunt..., dz. cyt., s. 475.

${ }^{44}$ L. Wittgenstein, dz. cyt.

${ }^{45}$ Tenże, Dehumanizacja.., dz. cyt., s. 369.

${ }^{46}$ Tamże, s. 373.
} 
myślenia i pod pozorem, że nie dotyka absolutu, absolutnie o wszystkim decydować" ${ }^{47}$. Ten podstęp, który na szeroką skalę realizuje się w naukach pozytywnych, zauważył też Nietzsche: „Nie ufam systematykom [...]. Pożądanie systemu jest brakiem rzetelności”"48. Trzymanie się metody lub systemu pozbawia nas czujnej uwagi i wytrwałej przytomności. „Myśl, jak każdy ruch, osiąga satysfakcję [...] kiedy istnieć przestaje" ${ }^{39}$. Rozum zadowala się wyjaśnieniem w formie metody, którą może niemalże mechanicznie, czyli bez udziału myślenia, realizować. Nietzsche mówi nie tylko o satysfakcji ale wręcz o rozkoszy, i podaje psychologiczne wyjaśnienie zjawiska inercji umysłowej: „Sprowadzając coś nieznanego do czegoś znanego, doznajemy poczucia ulgi [...]. $Z$ nieznanem łączy się niebezpieczeństwo, niepokój, troska - instynkt zmierza przede wszystkiem do usunięcia tych stanów. Pierwsza zasada: jakiekolwiek objaśnienie lepsze jest od żadnego. [...] pierwsze lepsze wyobrażenie, za pomocą którego nieznane daje się objaśnić jako coś znanego, napawa taką błogością, iż «przyjmujemy je za prawdę». Dowód rozkoszy («mocy») występuje jako kryterium prawdy"50. Historia zatoczyła koło, a lekarstwo stało się trucizną. Racjonalność ocaliła Ateńczyków przed samobójczym instynktem dążącym do rozkoszy cielesnej. A teraz człowiek w dążeniu do rozkoszy rozumu traci kontakt $\mathrm{z}$ rzeczywistością, zatracając się w pozornych jej obrazach.

Rozumowanie czyste, bez zaczepienia w rzeczywistości, buja w obłokach idei. Zaczepami ratio $\mathrm{w}$ rei są pojęcia. Mieć pojęcie to jednak zupełnie coś innego, niż mieć definicję. Mieć pojęcie to nie rzecz intelektu. Pojęcie się czuje raczej niż rozumie. Rozumie się struktury. Pojęcia nabywa się przez doświadczania. Pojęcie to pamięć doświadczenia. Traci się pojęcie, gdy zapomina się o doświadczeniu. Są doświadczenia myślowe, można doświadczać abstrakcyjnej liczby, można doświadczać rzeczywistego stołu. Definicje to próby utrwalenia doświadczenia w strukturze. Mieć pojęcie, to znaczy, mieć pamięć bezpośrednią. Mieć definicję, to znaczy, mieć pamięć pośrednią, ślad rzeczy odciśnięty w strukturze. Należy bezustannie, wciąż na nowo doświadczać, aby utrzymywać $\mathrm{w}$ pamięci pojęcia $\mathrm{w}$ ich prawdziwej formie, adekwatnej do treści. $\mathrm{W}$ przeciwnym razie utracimy pojęcie, a pozostanie tylko ich definicyjny ślad. Definicje są

\footnotetext{
${ }^{47}$ H. Bergson, Ewolucja..., dz. cyt., s. 215.

${ }^{48}$ F. Nietzsche, Zmierzch..., dz. cyt., s. 9.

${ }^{49}$ L. Kołakowski, Pochwata niekonsekwencji, Londyn 1989, s. 169.

${ }^{50}$ F. Nietzsche, Zmierzch..., dz. cyt., s. 45.
} 
tylko obrazami, pozorami. Relacje między pozorami są równie pozorne. Więc nauka pozbawiona pojęć zajmuje się pozornymi problemami, które sama tworzy. „Rozbieżność między rzeczami i czystymi ideami - pisze Ortega - jest tak wielka, że musi w sposób nieunikniony prowadzić do sprzeczności. Jednakże racjonalista nie wątpi, że w tym przypadku ustąpić musi rzeczywistość. [...] Rzeczywistość ma jednak aż nadto siły, by stawić opór szturmowi idei. Racjonalizm znajduje zatem inne wyjście: uznaje, że w chwili obecnej myśl nie może się zrealizować, lecz że stanie się tak w procesie nieskończonym" ${ }^{51}$. Owoce racjonalizmu są pewne ale nieskończenie odległe. Jednostka nie ma szans ich dosięgnąć. Droga racjonalnego poznania jest żmudna, ale za to najmniej ryzykowna. Jednak jest ona za długa, bo dłuższa niż życie pojedynczego człowieka. A co, jeśli ryzyko irracjonalizmu jest tylko pozorne? Jeśli strach przed niezrozumianym jest iluzją rozumu?

„Zamiast dostosowywać myślenie do rzeczy, w utopii zakłada się, że rzeczywistość przystosuje się do abstrakcyjnych, formalistycznych kształtów nakreślonych przez pozostawiony samemu sobie umys" ${ }^{\prime 2}$. Utopia to abstrahowanie od rzeczywistości. „Myślenie utopijne to porzucenie intuicji konkretu, lekceważenie jej" ${ }^{53}$. A konkret to sztuka. To tłumaczy, dlaczego nauka lekceważy sztukę, jako metodę poznawczą.

„Gdyby zmysły i świadomość miały zasięg nieograniczony, [...] niepotrzebne byłyby myślenie pojęciowe i rozumowanie" ${ }^{n 4}$. Jednak na drodze rozumowania naukowego napotykamy ograniczenie innego rodzaju. „Na każdą konkretną rzecz składa się nieskończona suma relacji. Nauka posuwa się stopniowo naprzód odkrywając jedną relację po drugiej i wobec tego potrzebuje nieskończonego czasu, by je wszystkie ustalić. Zmierzanie do celu, którego nigdy nie da się w pełni osiągnąć, to właśnie podstawowa tragedia nauki. $Z$ tragedii nauki rodzi się sztuka. Metody artystyczna wkraczają wówczas, kiedy zaczynają zawodzić metody naukowe. Jeśli abstrakcje i generalizacje nazwiemy metodami naukowymi, to odpowiednio metodami artystycznymi będą indywidualizacja i konkretyzacja" „5. Sztuka potrafi objąć to, co nauka uważa za nieskończone, a tym samym, za niemożliwe do ustalenia. Problem nieskończoności nie dotyczy

\footnotetext{
${ }^{51}$ J. Ortega y Gasset, Po co..., dz. cyt., s. 123-124.

${ }^{52}$ Tenże, Dehumanizacja..., dz. cyt., s. 372.

${ }^{53}$ Tamże, s. 374.

${ }^{54}$ H. Bergson, Postrzeżenie.., dz. cyt., s. 249.

${ }^{55}$ J. Ortega y Gasset, Debumanizacja..., dz. cyt., s. 59.
} 
sztuki. Czy to przypadek, że wybitne wytwory sztuki nazywa się „dziełami skończonymi”? Z kolei wytwory nauki funkcjonują jako „ustalenia naukowe”. Czy ustalenie nie jest zatrzymaniem, pozbawieniem ruchu?

\section{Indywidualność sztuki}

To, co nie daje się uchwycić w naukowym obrazie świata, mianowicie zmiana i ruch, wydaje się być dostępne oglądowi estetycznemu. Nauka dostrzegając wyłącznie to, co stałe, dzieli każdą zmianę na etapy. Szuka idealnego parametru, czyli tego, co jest wspólne na każdym etapie zmiany i zajmuje się tylko tym wyabstrahowanym fragmentem, który się powtarza, gdy całość się zmienia. Nauka jest pod tym względem przeciwieństwem sztuki, którą interesuje niepowtarzalność, konkret i całość. Jak wszelkie przeciwieństwa, także nauka i sztuka posiadają wspólny wymiar. Obydwu tym dziedzinom przyświeca cel poznawczy, obie są na drodze dążenia do prawdy.

Zdaniem Ortegi tym, co odnajduje nauka szukając stałości, są sztywne pojęcia i na nich się zatrzymuje. „Dla nauki nie rzeczy są ważne, lecz system znaków, którymi można je zastąpić. Sztuka przeciwnie, odbywa drogę od znaku do samej rzeczy" ${ }^{56}$. Bergson i Ortega zdają się mówić jednym głosem, że ogląd estetyczny pozwala spojrzeć poza sztywną siatkę pojęciową, zasłaniającą rzeczywistość. „Miedzy naturą a nami, cóż mówię - między nami a naszą świadomością pojawia się zasłona, nieprzejrzysta dla zwykłych ludzi, lekka, niemal przezroczysta dla artysty i poety” ${ }^{57}$. Artysta, jeśli „przełamie nasze uprzedzenie do formy”, które staje między nami a rzeczywistością, osiągnie „najwyższą ambicje sztuki, polegającą na objawieniu nam natury" ${ }^{\prime 3}$. Sztuka przekracza wszelkie konwencje i łamie reguły, ale w tym jest jej wartość poznawcza. Ten nonkonformizm sztuki pozwala na bezpośredni kontakt ze światem, co zauważa Bergson, gdy twierdzi, że „sztuka nie ma innego celu, jak usuwanie praktycznie użytecznych symboli, konwencjonalnie i społecznie przyjętych abstrakcji, wreszcie tego wszystkiego, co przesłania nam rzeczywistość, aby postawić nas oko w oko z samą rzeczywistością”59. Sztuka, a w szczególności poezja, jest sprzeczna „z dobrze utrwalony-

\footnotetext{
56 Tamże, s. 329-330.

${ }^{57}$ H. Bergson, Śmiech, dz. cyt., s. 190.

58 Tamże, s. 193.

59 Tamże, s. 194.
} 
mi zwyczajami językowymi” ${ }^{00}$, a absurdalność, jak powiedziałby Feyerabend, znamionuje twierdzenia rewolucyjne. Nonkonformizm sztuki stanowi zatem jej rewolucyjny potencjał $\mathrm{w}$ dziedzinie poznania.

Język metaforyczny jest alternatywną dla matematyki próbą opisu rzeczywistości, i nie jest to alternatywa rozłączna. Można powiedzieć za Ortegą, że „Poezja jest obecnie wyższą algebra metafor" ${ }^{\prime 61}$. Różnica polega na tym, że matematyka zajmuje się abstrakcjami, a sztuka konkretami. Bergsona twierdzi, że „sztuka zawsze zmierza ku temu, co indywidualne” ${ }^{2}$, a Ortega zauważa, że „w sztuce powtórzenie jest niczym”33. Za wartością poznawczą sztuki, która pielęgnuje indywidualność, stoi też fakt, że konkret jest podstawowym znamieniem rzeczywistości. Georg Wilhelm Friedrich Hegel, pisał: „Jestem przekonany, że najwyższym aktem rozumu, aktem, w którym rozum obejmuje wszystkie idee, jest akt estetyczny, że prawda i dobro spokrewniają się tylko w pięknie" Podobnie Ortega przypisuje ujęciu estetycznemu ogromne możliwości. Uznaje on rolę sztuki w procesie poznania życia ludzkiego za kluczową i wieńczącą ten proces. „Człowiek nosi w sobie tragiczno-heroiczny problem, nauka to pierwszy stopień rozwiązania tego problemu, moralność - drugi, a sztuka - trzeci” ${ }^{\prime \prime}$.

\section{Bezinteresowność filozofii}

Bergson uważał, że problem niezrozumienia ruchu, jest przyczyną „nieprzezwyciężonych" trudności filozoficznych, a także generuje antagonistyczne systemy filozoficzne. „Mówimy, że zmiana istnieje, że wszystko się zmienia, [...] ale to są tylko słowa, rozumujemy zaś i filozofujemy tak, jak gdyby zmiany nie było" ${ }^{\prime 6}$. Zwraca on uwagę na fakt, że rozwijając myślenie pojęciowe „skazuje się na eliminowanie z rzeczywistości wielu różnic jakościowych, na częściowe otępianie naszych postrzeżeń” ${ }^{67}$. Proponuje on „drążyć i poszerzać” nasze po-

\footnotetext{
${ }^{60}$ P. K. Feyerabend, dz. cyt., s. 54.

${ }^{61}$ J. Ortega y Gasset, Dehumanizacja..., dz. cyt., s. 304.

${ }^{62}$ H. Bergson, Śmiech, dz. cyt., s. 196.

${ }^{63} \mathrm{~J}$. Ortega y Gasset, Dehumanizacja..., dz. cyt., s. 287.

${ }^{64}$ G. W. F. Hegel, Pisma wczesne z filozofii religii, przeł. G. Sowinski, Kraków 1999, s. 276.

${ }^{65}$ R. Gaj, dz. cyt., s. 136.

${ }^{66}$ H. Bergson, Postrzeżenie..., dz. cyt., s. 248.

${ }^{67}$ Tamże, s. 251.
} 
strzeganie, zamiast wznosić się ponad nie. Są ludzie, którzy pomagają nam rozszerzać postrzeganie, widzą i ukazują nam „to, czego nie dostrzegamy w sposób naturalny. Ludźmi tymi są artyści" ${ }^{68}$. Widzą oni więcej, bo patrzą bezinteresownie, „dla niczego, dla przyjemności”69. Zadaniem filozofii byłoby więc, według Bergsona, poszerzanie naszej uwagi poprzez odwracanie jej od „praktycznego zainteresowania światem i skierowanie jej ku temu, co praktycznie niczemu nie służy"70.

\section{Irracjonalność rzeczywistości}

Niezaspokojona potrzeba pewności jest tym, co nas zmusza do myślenia „Człowiek kiedy wie, czego się trzymać [...], nie myśli, [...] Myślenie jest tym, co robimy - cokolwiek by to było - aby wydostać się z wątpliwości [...]. Chcąc tego czy nie, człowiek [...] musi poszukiwać pewności. To go odróżnia od zwierząt i bogów" "1. Jednak nie posiadanie pewność, ale właśnie jej poszukiwanie innymi słowy zagubienie - to człowieczeństwo. A wyznanie: wiem, że nic nie wiem - to wyznanie człowieka. Świadomość niewiedzy i związana z tym niepewność to pierwszy krok ku mądrości. Wybitny fizyk Richard P. Feynman twierdzi, że „stan niepewności jest siłą życiową naukowca”72. Odrzucenie stanu pewności przynosi radykalną zmianę: „Rozum przestaje być normą rządzącą, stając się arsenałem narzędzi"73.

Racjonalizacja to krok ku pewności, jednak krok fałszywy. Parmenides i jego uczniowie nie znaleźli pewności, tylko po prostu przestali jej szukać w rzeczywistości. Stworzyli sobie pewność idealną. „Eleatyzm stanowił radykalną intelektualizacje bytu”, przypisał on temu, co rzeczywiste właściwości pojęć. Tym właśnie utrudnia „zrozumienie zjawisk ludzkich [...]. Wyrzeknijmy się zatem [...] wygodnego założenia, iż rzeczywistość jest logiczna, i uznajmy, że logiczna jest jedynie myśl"74.

\footnotetext{
${ }^{68}$ Tamże, s. 252.

${ }^{69}$ Tamże, s. 255.

${ }^{70}$ Tamże.

${ }^{71}$ J. Ortega y Gasset, Uwagi..., dz. cyt., s. 274.

${ }^{72}$ R. P. Feynman, Przyjemność poznawania, przeł. K. Karpińska, Warszawa 1999, s. 213.

${ }^{73}$ J. Ortega y Gasset, Po co..., dz. cyt., s. 126.

${ }^{74}$ Tamże, s. 187.
} 
Człowiek „nadal wierzy, że rozum służy do czegoś, co jest konieczne, ale nie wie dobrze, do czego. Jest tylko pewny, że jego funkcja jest inna od tej, którą mu wyznaczono w ciągu ostatnich trzech wieków. [...] Podsumowując, zamiast być wielkim rozwiązaniem, inteligencja przekształciła się nam w wielki problem"75. W tej sytuacji Ortega proponuje racjowitalizm, który - jak sam twierdzi - nie przeciwstawia się rozumowi. „Nie akceptuje jedynie wyłączności racjonalizmu”76, charakteryzującego się swoistą ślepotą polegającą „na celowym niedostrzeganiu irracjonalności"77, w którą rozum popada zawsze, gdy zajmuje się problemem rzeczywistości, dostępnej w nieskończenie złożonych zjawiskach.

\section{MISUNDERSTANDING OF THE MOVEMENT AND ITS CONSEQUENCES}

\section{Summary}

We do not understand the movement that we experience continually. On the other hand, we understand constancy that we cannot experience. In my opinion, it is a prime reason for apparent and unsolvable philosophical problems. Language cannot describe empirical experience adequately. This gap between rational thinking and sensual data can be bridged with the help of metaphor.

Key words: movement, metaphor, language, art, irrationalism, ratiovitalism

Słowa kluczowe: ruch, język, metafora, sztuka, irracjonalizm, racjowitalizm

\section{Bibliografia}

Arystoteles, Retoryka, Retoryka dla Aleksandra, Poetyka, przeł. Henryk Podbielski, Warszawa, PWN, 2009.

Bergson Henri, Ewolucja twórcza, przeł. Florian Znaniecki [W:] Wojnar Iwona, Bergson, Warszawa, Wiedza Powszechna, 1985.

Bergson Henri, Postrzeżenie zmiany, przeł. Paweł Beylin [W:] Wojnar Iwona, Bergson, Warszawa, Wiedza Powszechna, 1985.

Bergson Henri, Śmiech, przeł. Iwona Wojnar [W:] Wojnar Iwona, Bergson, Warszawa, Wiedza Powszechna, 1985.

Feyerabend Paul K., Jak być dobrym empirysta?, przeł. Krystyna Zamiara, Warszawa, PWN, 1979 Feynman Richard P., Przyjemnośc poznazwania, przeł. Katarzyna Karpińska, Warszawa, Prószyński i S-ka, 1999.

\footnotetext{
75 Tenże, Uwagi..., dz. cyt., s. 268.

${ }^{76}$ Tenże, Po co..., dz. cyt., s. 133.

77 Tamże, s. 138.
} 
Gaj Ryszard, Ortega y Gasset, Warszawa, Wiedza Powszechna, 2007.

Hegel Georg W. F., Najstarszy program systemy niemieckiego idealizmu, przeł. Grzegorz Sowinski [W:] Tenże, Pisma wczesne z filozofii religii, Kraków, Znak, 1999.

Kołakowski Leszek, Pochwata niekonsekwencji, Londyn, NOWA, 1989.

Lakoff Georg, Johnson Mark, Metafory w naszym życiu, przeł. Tomasz P. Krzeszowski, Warszawa, ALETHEIA, 2010.

Nietzsche Fryderyk, Poza dobrem i ztem, Wyd. 3, przeł. Stanisław Wyrzykowski, Warszawa, 1911.

Nietzsche Fryderyk, Zmierzch bożyszcz, przeł. Stanisław Wyrzykowski, Warszawa, bis, 1991.

Ortega y Gasset Jose, Bunt mas i inne pisma socjologiczne, przeł. Piotr Niklewicz, Henryk Woźniakowski, Warszawa, PWN, 1982.

Ortega y Gasset Jose., Dehumanizacja sztuki i inne eseje, przeł. Piotr Niklewicz, Warszawa, Czytelnik, 1980.

Ortega y Gasset Jose, Po co wracamy do filozofii?, przeł. Ewa Burska, Magda Iwińska, Anna Jancewicz, Warszawa, SPACJA, 1992.

Ortega y Gasset Jose, Uwagi o myśleniu, jego teurgia i jego demiurgia, przet. Ryszard Gaj, [W:] Ryszard Gaj, Ortega, Warszawa, Wiedza Powszechna, 2007.

Schiller Fryderyk, Listy o estetycznym wychowaniu cztowieka i inne rozprawy, przeł. Irena Krońska, Jerzy Prokopiuk, Warszawa, Czytelnik, 1972.

Wittgenstein Ludwig, Tractatus Logico-philosophicus, przeł. Bogusław Wolniewicz, Warszawa, PWN, 2000.

Krzysztof Ostasz, absolwent kierunku fizyka (magister, UwB) i filozofia (licencjat, UwB), były pracownik naukowy Instytuty Fizyki Doświadczalnej UwB. 